\title{
Addressing the political dynamics of radicalization leading to religious extremism in Bangladesh
}

\author{
Md. Nazmul Arefin ${ }^{1 *}$, Nousheen Sharmila Ritu ${ }^{2}$ \\ ${ }^{1}$ Independent Researcher, Bangladesh \\ ${ }^{2}$ United Nations Office on Drugs and Crime (UNODC), Bangladesh \\ * Corresponding author \\ E-mail address: nazmularefin.du@gmail.com \\ DOI: https://doi.org/10.21107/sml.v4i1.10543
}

\begin{tabular}{|c|c|}
\hline Article Info & Abstract \\
\hline $\begin{array}{l}\text { Keywords: } \\
\text { politics of terrorism } \\
\text { religious extremism } \\
\text { radicalization } \\
\text { South Asia } \\
\text { Bangladesh }\end{array}$ & $\begin{array}{l}\text { When radicalization and religious extremism is predominantly perceived } \\
\text { through the prism of ' } 9 / 11^{\prime} \text { and/or 'Post-Soviet Muslim radicalization', } \\
\text { there is a danger of oversimplifying the phenomenon of extremism for } \\
\text { majoritarian Muslim societies like Bangladesh. To understand the dynamics } \\
\text { of religious radicalization, it is imperative to devise a political genealogy } \\
\text { and identify both micro and macro level political drivers of radicalization by } \\
\text { addressing the political histories, catalysts, and risk factors related to religious } \\
\text { extremism. Considering the paucity of research on this particular area, this } \\
\text { paper sets out to understand and address the political drivers that facilitate } \\
\text { the process of radicalization leading to religious extremism in Bangladesh. } \\
\text { Adopting qualitative approach, this paper has conducted content analysis of } \\
\text { pertinent secondary sources based on predetermined sets of categories for } \\
\text { analysis. The results indicate that explicit support by the military rulers for } \\
\text { Islamic orthodoxy, culture of political opportunism in democratic regimes } \\
\text { and weak governance are some of the major political drivers of radicalization } \\
\text { and religious extremism in the country. At a regional and global level, } \\
\text { insurgency and separatist movements in neighborhood countries, global } \\
\text { political environment of confrontation between the West and the Muslim } \\
\text { World and the identity politics altogether fostered radicalization leading to } \\
\text { religious extremism in Bangladesh. }\end{array}$ \\
\hline
\end{tabular}

Citation suggestion:

Arefin, M. N., \& Ritu, N. S. (2021). Explaining political dynamics of radicalization leading to religious extremism in Bangladesh. Simulacra, 4(1), 115-129. https://doi.org/10.21107/sml.v4i1.10543

Received 30 April 2021; Received in revised form 15 May 2021; Accepted 25 May 2021; Published online 25 June 2021. 


\section{Introduction}

Much of what we perceive as religious extremism today is shaped by the global event of 9/11 attack and the ensuing narratives that were formed and predominated within the mainstream discourses of religious extremism (Cainkar, 2009, as cited in Wibisono, Louis \& Jetten, 2019). While it is undeniable that there are indeed imperceptible effects of global political events on issues such as religious extremism, there is also the risk of simplifying something as complex as radicalization and religious extremism when it is consistently associated with just one big global event. For the purpose of this study, religious extremism refers to the commitment to radical ideological beliefs often following the pursuit of struggle for religious identity leading towards group based violence that might be incited by perceived injustice (Silber \& Bhatt, 2007; Sageman, 2008; Njoku \& Akintayo, 2018). There are multifarious dimensions to religious extremism each of which stems and thrives from both global and local factors along the line. Hence, if the phenomenon of religious extremism is to be understood eclectically, it has to be done by taking into consideration both the micro and macro level political drivers that create the vulnerability to radicalization and abets violence and extremism.

Mainstream discourses on religious extremism are overridden by the international security narrative that have consistently identified isolated incidents of religious extremism as a part of Post-Soviet Muslim radicalization process; this has been the case even though evidence suggests that much of the incidents of religious extremism, particularly in Central Asia have been 'localized and inhibited by secularization as much as it is driven by radicalization' (Heathershaw \& Montgomery, 2014). But the tendency of elucidating religious extremism to a unidimensional construct is not just reductionist, it also fails to encompass the theological, social and political aspects of religious extremism distinctly across the context of different countries (Wibisono, Louis \& Jetten, 2019). Which is why in addition to taking into account the global political drivers, it is imperative to contextualize religious extremism with the local and regional political genealogy, conflict and risk factors that facilitate the process of religious extremism.

Religious extremism in Bangladesh can be traced back to as early as the country's journey as an independent nation (Mostofa \& Doyle, 2019). The current ruling party of Bangladesh and even the ones before that has consistently denied any presence or possibility of homegrown terrorism in connection to terroristactivities in the country. However, a study into the political trajectory of the country reveals that circumstances and activities espoused by the key political actors have paved the path for religious extremism in the country (Lorch, 2020). The political trajectory of the country has been embroiled with contestation of power between the two major political parties - Awami League (AL) and Bangladesh Nationalist Party (BNP) during elections and ensuing party politics and violence (Herbert, 2019). The emergence of religious extremism took rise against the context of rising Islamic orthodoxy in the country due to the replacement of secular values with increasing conformation to religious extremist organizations in an effort of legitimizing and garnering mainstream support for the ruling parties (Hassan \& Nazneen, 2017). In that due course, religious extremist organizations became increasingly expansive and operational throughout the country. On the other hand, weak governance coupled with the persistent blame game between the two major political parties of the country have persistently undermined the transparency and efficacy of counter terrorism efforts in the country. 
However, up until the Holey Artisan terrorist attack in 1 July, 2016 and killing of atheist bloggers like Avijit Roy, Washiqur Rahman, Ananta Bijoy Das, Niloy Chatterjee, Nazimuddin Samad, and others during the period of 2015-2017, not much attention was devoted in understanding the global factors that might contribute to the incidents of religious extremism in Bangladesh. Against that context, the purpose of this paper is to develop an understanding of religious extremism specifically in the context of Bangladesh through the unified lens of local, regional and global political drivers. While bringing into account the domestic political factors like contesting power politics, lack of legitimacy and governance resulting into violence, the paper also addresses the impact of regional separatist movements within India and Pakistan in subjecting Bangladesh towards insurgency and religious extremism. It also highlights the global political factors involving persecution of Muslims around the globe, impact of global events on homegrown terrorism and the politics of resentment and identity crisis in today's increasingly globalized world.

\section{Method}

The paper has adopted a qualitative approach in seeking to understand the major political factors that are involved with radicalization and eventually leading to religious extremism, particularly in the context of Bangladesh. Qualitative methodology has been deemed to be the most pertinent in this context given this approach of inquiry is best suited in developing understanding of a reality, describing and explaining its bearing within its social world (Morse \& Field, 1996). And since there can be no singular objective reality for a phenomenon as complex as radicalization and religious extremism, qualitative methods of inquiry have the best shot in encompassing the narratives that have been represented in the academic literature striving in depicting an interpretation of this phenomenon. Even though content analysis can be treated both as a qualitative and quantitative research method, it is also largely helpful in identifying and analyzing the presence and meanings of such concepts in communicative language within a naturalistic paradigm (Hsieh \& Shannon, 2005).

The purpose of the content analysis has been to identify the patterns of findings and arguments relevant to the political dynamics of radicalization and religious extremism in Bangladesh. Hence, through a directed and inductive content analysis approach, relevant research findings in written text forms from secondary sources including relevant books, journals, articles, newspapers, magazines and other publications have been used to identify and connect together the major political drivers influencing radicalization and religious extremism in Bangladesh. To conduct the content analysis, at first two distinct broad of categories, i.e., domestic political dimensions and global domestic dimensions of radicalization and religious extremism were developed under which the units of meaning were to be coded and analyzed.

Thebroad categories were further divided into sub categories like impact of Islamic orthodoxy, political opportunism of religion, issues of governance, etc. Next, a word search was conducted on the internet using keywords like 'radicalization', 'religious extremism in Bangladesh', '9-11 terror attack', 'Post-Soviet radicalization discourse', and 'political dynamics of radicalization' to filter the relevant articles and research findings. The filtered results were posited within the two categories and analyzed to identify the connection with each of the dynamics. The findings led to a discussion how the political dynamics of radicalization and religious extremism is multifarious stemming from 
different historical timelines and landscapes; nonetheless, these realities continue to shape the course of these phenomena even in Bangladesh.

\section{Results and Discussion}

\section{Domestic dynamics}

The rise of Islamic orthodoxy as a breeding ground

When attempting to contextualize religious extremism in Bangladesh, it is essential to take a step back and assess the contribution of the political milieu of the country in expediting support and fostering breeding ground for religious extremism. Even though Bangladesh as an independent country started its journey under the leadership of Bangabandhu Sheikh Mujibur Rahman upon the pillars of nationalism, socialism, democracy and secularism, these values were soon to be brushed aside (Lorch, 2020). Even though the military rule of Major Ziaur Rahman is said to initiate for the first time an explicit support for Islamic orthodoxy in the country, inclination towards Middle Eastern countries can be traced back to the early period of Mujib's regime as well. Afterwards the independence of 1971, understanding the economic importance of Middle Eastern countries, Mujib began to espouse an Islamic component to nationalism in Bangladesh and began participating in the meetings of Organization of the Islamic Conference (OIC). He also reportedly sent a group of Bangladeshi doctors to assist Arab allies during the Yom Kippur War against Israel in 1973 (Griffiths \& Hasan, 2015). This increased affinity towards adopting religion as a political tool was further augmented during the regimes of Major General Ziaur Rahman (1975-1981) and Hussein Mohammad Ershad (1982-1990) respectively.
Soon the article of secularism was replaced with Islam as the state religion-a policy that was followed by number of other similar strategic ventures like inclusion of Islamic studies as mandatory topic for schools, proliferation of mosques, madrasas and Islamic universities with state patronage and inclusion of Islamists in the state cabinet (Griffiths \& Hasan, 2015; Hasan, 2012; Lorch, 2020). Even though all of these policies may seem peripheral to the political context of the country, in hindsight it is to be seen that these strategic actions have essentially initiated a process of Islamization in the country. Eventually, this disintegration of secular values added with proliferation of Islamist movements and organizations have facilitated the development of Islamist organizations who later exploited these conditions to perpetrate acts of religious extremism across the country.

Towards the end of the 1970s, instead of persecuting Jamaat-e-Islami Bangladesh for their collaborative role in the genocide in 1971, Ziaur Rahman lifted a ban on religious politics and allowed the party to engage in grassroots development and politics (Allchin, 2019, p. 84). In order to penetrate the grassroots both the dictators, Ziaur Rahman and Hussain Muhammad Ershad adopted rural development policies that incorporated foreign-funded NGOs and the religious parties (Allchin, 2019). And this diffusion continues its legacy even in the post-Military period of Democratic Bangladesh.

\section{Political opportunism of the legitimacy of religion}

Time and time again across different contexts, it has been witnessed that secular governments have promoted Islamism and religious political parties for their own legitimacy or electoral gain (Lorch, 2018). There are several instances where secular governments co-opted with Islamist 
organizations or conformed to demands of these political bodies due to not only their widespread acceptability among the mainstream population, but also in order to exploit their ability of mobilizing collective actions (Butt, 2016; Buehler, 2013). Consistent to those practices, secular governments have teamed up with Islamist actors to undermine the political competition posed by Islamist contenders (Camroux, 1996 and Kubicek, 2015 as cited in Lorch, 2018).

Even though the Awami League (AL) government proclaimed themselves to be advocates of secularism, their conformation to Islamist organizations and concession in criminalizing religious extremism depict a different picture. Be it the Awami League (AL) or Bangladesh Nationalist Party (BNP), both the regimes have appealed to Islam during their electoral campaigns in an effort of proving themselves to be relevant to the mainstream majoritarian Muslim population. Concomitantly, this has correlated with growing number of Islamist parties seeking to replace secular constitution of Bangladesh with the Sharia law. Post 9/11, this backdrop allowed Bangladesh to be one of the many bases for globally networked Islamists declaring jihad against the West and the secular democracy in Bangladesh. Eventually, this entailed the patronization of organizations like Jamat-ul-Mujahideen Bangladesh (JMB), Harkat ul Jihadi Islami Bangladesh (HuJi-B), Jagrata Muslim Janata Bangladesh (JMJB), Ahle Hadith Andolon Bangladesh (AHAB), most of whom were responsible for the subsequent terrorist attacks across the country (Griffiths \& Hasan, 2015). It is reported that HuJI-B is backed by the Taliban and was officially banned by the government in 2005; similarly JMB has an extensive network and follows the Taliban's ideals (Asia Foundation, 2017).

Even though the Awami League tried to restore some balance between Islamism and secularism in the country following the 2008 electoral win, there yet seems to be a lack of transparency and resolution in interdicting these Islamist forces and actors. Meanwhile, extremist organizations exploited this leeway in garnering increased support for their cause and launching extremist attacks across the country.

Following the the Awami League government's establishment of the International Crimes Tribunal to punish the 1971 war criminals, the Shahbagh Movement came to the fore in 2013 demanding execution of the war criminals. The movement soon engendered heated opposition from a newly formed organization namely Hefazat e Islam who demanded action against atheists and blasphemous bloggers of the Shahbagh movement. They further put forward a 13 point demand which included provisions like reinstating the phrase "Absolute faith and trust in Allah" in the constitution; legislate capital punishment for maligning Allah, Islam and the Prophet; stop killing or arresting madrasa students and Islamic scholars; ban foreign cultures like free mixing of opposite genders; remove sculptures from all across the country; make Islamic education mandatory in primary to higher secondary levels while removing women and education policy (Dewan, 2013; "Bangladeshi Clerics Fight Against", 2013). The Hefazat e Islami with their massive number of supporters and the ability of mobilizing them readily posed a significant threat to the stability of the AL government.

\section{Weak governance and the ensuing blame game}

There is a plethora of literature that has established the role of political maladies like corruption, political instability, repression of opposition and poor governance as drivers for extremism or terrorism (Campos \& Gassebner, 2007; Suleiman \& Karim, 2015; Simpson, 2014). These findings can be contextualized in Bangladesh as well given 
how political factors like corruption, weak state apparatus and marginalization of the opposition are persistent in the country. Riaz (2014) notes in this regard, "If the ruling party continues to marginalize the opposition, deny it the space for peaceful protest, and disregard the need for a political roadmap for moving forward, it will encourage extremists to take over". But evidently, for the Bangladeshi government, the major threat has not been religious terrorism, rather the presence or potency of the opposition party.

Both Bangladesh Nationalist Party (BNP) and Awami League (AL) have either invalidated the prevalence of religious extremism in the country or put the blame upon the respective opposition parties. Following the Holey Artisan attack in July, 2016, Prime Minister Sheikh Hasina alleged JMB and BNP members as the actors responsible while BNP leaders claimed that the AL government has intentionally incited terrorist attacks in the country to gain international sympathy while dodging the criminal responsibility on BNP (Lorch, 2020). Consistently denying the possible presence or involvement of international terrorist organizations like Islamic State (IS) or Al Qaeda, Prime Minister Sheikh Hasina also went on asserting, "The BNP-Jamaat nexus has been engaged in such secret and heinous murders in various forms to destabilize the country. The British government should take more steps on the ground. Jamaat has a strong influence in East London" (Ganguly \& Riaz, 2016).

The government responded in this same pattern even after the numerous attacks on secular bloggers, atheists, LBTQ activists, refusing to acknowledge any threat other than the political opposition (Ganguly, 2016). However, what this ensuing blame game does is that it undermines the collective efforts in countering extremism by allowing the actual perpetrating organizations to exploit this indeterminate and disoriented space to further pursue their schemes and activities. In this regard, Eqbal Ahmed aptly noted, "Officials don't define terrorism because definitions involve a commitment to analysis, comprehension and adherence to norms of consistency" (Combs, 2017). Quite similarly, when there is an absence of consensus regarding the source of threat and governments are busy playing the blame game with their rivals, no effective counter terrorism policy or strategy can ever be adopted or implemented.

\section{International dynamics}

\section{Regional politics and conflicted neighborhood}

After the bloody coup of 1975, the military rulers had revived the Pakistani policy of sheltering and supporting separatist rebel groups from Northeast India (Bhaumik, 2004). Joseph Allchin (2019) shows in his work that, even in the each democratic regime of BNP, Bangladesh became an accommodating place for India's separatists. Pakistan's Inter-Services Intelligence (ISI) has used the governments to establish contact with some of the rebel groups from Northeast India (Bhaumik, 2004). As part of their regional politics, Pakistani intelligence agency was actively helping the insurgent groups in the borders of Bangladesh to dismember India, in the same way that India had played a role in dividing Pakistan in 1971 (Allchin, 2019, p. 113).

Along with the political conflicts of the two regional hegemons, the insurgents in Kashmir and the subsequent emergence of the Hizb-ul-Mujahideen, the Pan-Islamist vision of Lashkar-e-Taiba in Pakistan, the dangerous politics of terrorism of America and China with Pakistan, the role of Myanmar's military junta in regional ethnic politics, demonization of the Rohingya Muslims and the genocide against them time 
to time played imperative roles behind the rise of religious radicalization and terrorism in Bangladesh (Riaz \& Fair, 2015; Riaz, 2017; Allchin, 2019).

\section{Influence of global politics on homegrown terrorism}

Both the Afghan War and the 9/11 attack have a huge contributory role in the trajectory of religious extremism across different countries including Bangladesh. In 1979, after the Soviets invaded Afghanistan, the world saw the rise of the Taliban. The U.S. then supported them with aid and money to fight against the Soviet (Whitlock, 2019). Then when in 2001 the U.S. army invaded Afghanistan, Talibans transformed from a group fighting for freedom to a fullfledged terrorist organization. Though they initially came as a group who aimed to free their country from the invaders, soon they were considered to be one of the most feared terrorist organizations in the world. Once the war was over, the mujahideens sought to establish similar ideologies within their own country leading to the development of major terrorist organizations like Jamaat-ulMujahideen Bangladesh (JMB) and Harkatul-Jihad-al-Islam (HUJI-B) in Bangladesh. Organizations like HUJI-B were heard giving slogans like "We all will become Taliban and Bangladesh will become Afghanistan" (Raman, 2002). The first instance of organized religious extremism in Bangladesh was witnessed in 1986 when The Muslim Millat Bahini (MMB) under the leadership of Major Matiur Rahman who had connection with militants fighting in the Afghan War. It is said that almost 3400 Bangladeshis took part in the Afghan war who eventually returned to the country with stronger radical ideologies and greater knowledge of violent activism (Mostafa \& Doyle, 2019).

On the other hand, following the 9/11 attack and America's declaration of War on
Terror, the discourse on terrorism took a radical shift where Muslims and terrorists were treated congruently through a hegemonic discourse of orientalism (Jamil, 2014). The aftermath of this incident and the 'War on Terror' project launched by the West gave rise to the phenomena of Islamophobia and distorted imaging of Muslims as terrorists. Following the 9/11 attack, the West developed an increased sense of panic and fear over future anticipation of further extremist violence; what they also developed was a subliminal fear of the religion, i.e. the spread of Islamophobia through persistent prejudiced media portrayal of Muslims. Edward Said in his book "Covering Islam" (1981) upholds how the US media and social policy through negative representations and images have depicted Islam as hostile and belligerent following the Iranian Revolution of 1979 (Said, 1981). The result is evident as Kimberly Powell in his study on the US media coverage since the 9/11 found out that the public was quick at assuming perpetrators of any extremist attack as Muslim even before having any evidence or details of the attack and that Muslim as perpetrators and Christians as victims were the commonplace thing to be (as cited in Teitaulbam, 2017).

Eventually, this negative portrayal and Islamophobia not only creates a sense of fear or hatred in the community against this particular religion and its followers but also among the Muslims, it ignites a sense of discrimination, anger and vindictiveness against the West and its population which eventually creates a strong vulnerability for radicalization. One of the senior officers of Bangladesh Counter Terrorism Unit, DMP shared on this regard, "Islamophobia not only creates a sense of fear or hatred in the community against this particular religion and its followers but also among the Muslims, it ignites a sense of discrimination, anger and vindictiveness against the West and its population which eventually creates 
a strong vulnerability for radicalization (Dhaka Metropolitan Police, 2018, p. 50)."

Persecution of Muslims around the globe

While the 9/11 may seem distant past now, we're today witnessing no less instances of state terrorism, even though they're not discussed as much. State terrorism here is denoted as the deliberate act, use or threat of violence or intimidation carried out directly/ indirectly, funded or encouraged by the state, its agent or approved surrogate group against its citizens or as part of international terrorism (Walter, 1969; Jackson, 2009; Mitchell et al., 1986). The Kashmiri struggle for autonomy since 1947 has been met with violence and since then this crisis has been exploited by terrorist organizations like Al Qaeda, Harkat-ul-Mujahideen, Jaishe-Mohammed. According to an article published by The Conversation in August 2019, Kashmir is the most heavily militarized region in the world that has experienced gross human rights violations including gang rapes by military, mass disappearances of approximately 10,000 people, murder of 100,000 and torture of unaccountably so many more (Ahmed, 2019).

Twenty five hundred kilometers away from Kashmir, Muslim Uighurs continue to suffer a much similar fate in the detention centers in Xinjiang in the hands of Chinese authorities. Government officials report that approximately 2 million Uighurs and other Muslim groups have been detained in these camps since 2017 (Maizland, 2021; Ramzy \& Buckley, 2019). Information from fled detainees retells stories of torture, sexual abuse and forced renunciation of faith in these camps.

Looking back, we find such resemblance in earlier incidents as well. In 2003, the U.S. started the Iraq war and it lasted till 2011. The war occupying the present news is the Syrian civil war which started between rebels and the Syrian government. An estimate of 400,000 people has been killed or is missing, $53 \%$ of the total population has been displaced and the UN estimates that some 13.1 million people require some form of humanitarian support or help (BBC, 2018). On the other hand, the ethnic cleansing being carried out in Myanmar against Rohingya Muslims and the conflict situation between Israel-Palestine also have had huge impacts on the rest of the world. Though this has impacts on the whole world in some way, it affects the Muslims around the globe a lot more deeply. This widespread persecution of Muslims and an eventual sense of oppression and injustice have over the years emerged as a large source of radicalization for Muslims all over the world.

The impacts of global persecution of Muslims are hugely relevant within the common Muslims' psyche of Bangladesh as well due to the population's imagined sense of Muslim fraternity. Global players of terrorism have hence, exploited this vulnerability in channeling this sentiment into radicalized one. To strategically capitalize this culminated anger of the Muslims of South Asia including Bangladesh, the leader of Al-Qaeda Ayman al-Zawahiri launched AQIS or 'Al-Qaeda in the Indian Subcontinent' in 2014 (Reed, 2016; Allchin, 2019)[3]. Before establishing this new frontline of global jihadist movement, in January of 2014 Ayman al-Zawahiri released a heavily localized and incisive 30-mintue video which goes on to saying:

"The events in Bangladesh enjoy the blessings of both India and America, since their interests in fighting Islam overlap, and this why their bilateral relations are becoming stronger day by day...My dear Muslim brothers, thousands of people are being killed in the streets of Bangladesh without any guilt, except that they have come out 
to protest against the collusion of the anti-Islam secular government with a bunch of transgressing secularists who are heaping insults and vulgar abuses on Islam and the Prophet of Islam... It is then that we get to understand that 'human rights' are the rights of their man, and not the rights of our man. The events in Bangladesh and Burma are not too distant from the oppression and killings of Muslims in Kashmir or the racial cleansing in Assam, Gujarat and Ahmedabad either" (Allchin, 2019, p. 91).

The instigating video of Ayman alZawahiri is a clear indication of how global players are closely observing the events of Bangladesh and how they intend to lead the anger of the common Muslims into Islamist Militancy. Similarly, a 2018 national study on understanding radicalization conducted by Dhaka Metropolitan Police (DMP) found in their report that witnessing international conflicts in which Muslim communities are attacked continuously influences young individuals to be radicalized as $57.5 \%$ of the respondents from their opinion survey agreed to this statement. One of the senior officers from DMP adds that, "The persecution of Muslims all across the globe has been vitally used in creating a strong anti-Western emotion that ultimately prompts radicalization. The popular perception have been developed that the torture at Palestine in the Middle East is a result of Western Conspiracy, the torture on the Rohingyas is a Buddhist conspiracy and Hindu conspirators are to be blamed for the persecution for Muslims in India (Dhaka Metropolitan Police, 2018, p. 50)." This goes on to show how persecution of Muslims around the globe is a matter of extreme relevance and concern to the people of Bangladesh as well in terms of the need and network for radicalization and eventual religious extremism.

\section{Globalization and identity crisis}

As the world becomes a smaller place with globalization in place, people increasingly become aware of their cultural identity. On both a micro and macro level, nations fall into a classification of 'us vs. them' and strive to establish their identity and values as the dominant power. Each individual possesses multiple identities including racial, national, ethnic and other identities but Huntington claims that in this new world order cultural identity shall emerge as the most important identity for an individual that will split the world in cultural lines and thus turning cultural conflicts into global conflicts. He further adds that the need for cultural identities are further elevated by the socio-economic modernization that has created increased alienation, broken sense of solidarity and greater need for a sense of belongingness (Huntington, 1996).

There is increased evidence that cultural globalization has affected local identities to a large extent. With increased international travel, wireless communication and assimilation, today ideas, values and norms are being transmitted at a much greater pace and magnitude. This often leads to the effacing of local cultural values or autonomy (Islam, Wahab, Burmester \& Chowdhury, 2019). Spanish sociologist Manuel Castells in this regard claims that our today's world is guided by two salient and yet contrasting trends - globalization and integrity of identities. Globalization with the aid of capitalism and information technology has created a society where the dominant cultures are determined by media and other global content (Castells, 2005). Today individuals are constantly being exposed to prevailing or popular cultures and values that are much different to their individual norms and culture. In situations as such, an individual's cultural identity is not just 
limited to their unique values and beliefs, but it also shapes how they respond to contrasting or contradicting ideologies and practices. Most of the time, this creates chaos and confusion within individuals, especially today's youth who are not only more exposed to the pervasiveness of information technology, but also are less confident of their roots and identity.

Terrorists exploit this confusion, compel individuals to choose a binary identity and prioritize religious identity above any other beliefs or identity. Beginning in the 1970s, through Islamic Resurgence and other cultural revival movements, the Muslim immigrants in the West developed an increased sense of recognition and conformity to their Muslim identity. According to Huntington, the Islamic Resurgence is a crucial historical movement that has affected more than one-fifth of the human population by acting as a dominant 'source of identity, meaning, stability, legitimacy, development, power and hope, hope epitomized in the slogan "Islam is the solution" particularly for the Muslims.

This need for identity and a sense of purpose and belongingness extends its relevance in Bangladesh as well given how Bangladeshi youths and victims of radicalization have been perplexed over whether to take up their civic responsibility or to go save the Muslim world that is being persecuted in front of them, eventually making them susceptible to radicalization. In this regard, Associate Editor of Daily Star, Brig. General Shahed Anam Khan (Retd) shares in an interview, "Sometimes religious and secular scholars want you to choose between the national or religious identity. You have to either be a Bengali or a Muslim. But why is it that we have to adopt a binary identity by choosing either one of the two (Dhaka Metropolitan Police, 2018, p. 64)?" Besides, the social changes in Bangladesh in terms of urbanization, global integration, dislocation and displacement also have an effect on political identity as the country was suddenly exposed to the widespread radical ideas and networks (Nelson \& Oldmixon, 2017). This reality has been depicted particularly after the Holey Artisan attack in 2016 where masterminds of the attack belonged mostly from the Bangladeshi diaspora.

\section{Conclusion}

Radicalization and religious extremism are both complex phenomena that call for developing an inquiry that takes into account the unique and varying factors at play in the background. In order to disentangle these factors, it is imperative to expand the established contemporary and repetitious discourse whereby religious extremism has been invariably associated with the PostSoviet and 9/11 radicalization of Muslims. In pursuit of that goal, this paper attempts to encapsulate the political drivers of radicalization leading to religious extremism in Bangladesh both at a micro and macro level throughout the years. At a micro level, the political drivers stem from the country's own homegrown politics of partisan power contestation, exploitation of religion in securing mainstream legitimacy and weak governance. Outside the country's territory, political insurgency of the neighborhood regions also plays a significant role in making Bangladesh an interface for these separatist movements. On the other hand, while the post 9/11 realities should not be singularly treated as the sole causative factors, nonetheless, these factors continue to shape the need, narrative and network for radicalization and religious extremism in Bangladesh along with other countries.

The increasing identity crisis among the youth demographics has also emerged to be a political driver as terrorist networks continue to capitalize the resentment and 
need for identity and belongingness in this growing globalized world. However, there is a dearth of research that has been devoted in approaching radicalization or religious extremism from such a multifarious perspective. By bringing these varying political dimensions of the radicalization and religious extremism within a narrative, this paper seeks to initiate the expansion of understanding of religious extremism at an academic level. Moreover, this study is largely based on secondary sources so there are still large scopes of research into this topic that needs to be done at a larger scale using primary data. An increased concentration towards understanding radicalization and religious extremism from this kind of multidimensional approach can eventually emerge as the first step towards truly understanding and curbing this crisis.

\section{Acknowledgement}

The article has used certain aspects of a paper entitled 'Causes of Radicalization and a Counter Approach' which was a national study conducted by the Department of Criminology, University of Dhaka and commissioned by the Dhaka Metropolitan Police (DMP). The authors were part of this research project and so are grateful to the DMP for funding the study and contributing to the nation initiated effort towards understanding the phenomenon of extremism and its preventive policies.

\section{Declaration of Ownership}

This article is an original work written by the authors in name. All the works that have been used for the study has been duly acknowledged and properly referenced within the paper.

\section{Conflict of Interest}

There is no conflict of interest in this article.

\section{Ethical Clearance}

This article conforms to all the ethical standards and has been approved by the institution.

\section{References}

Ahmed, B. (2019). Call the crime in Kashmir by its name: Ongoing genocide. The Conversation. https://theconversation. com/call-the-crime-in-kashmir-by-itsname-ongoing-genocide-120412

Allchin, J. (2018). Many rivers, one sea: Bangladesh and the challenge of Islamic militancy. Hurst Publishers.

Asia Foundation. (2017). Bangladesh state of conflict and violence. https:// asiafoundation.org/wp-content/ uploads/2017/10/BangladeshStateofConflictand_Violence.pdf

Bangladeshi clerics fight against atheist bloggers. (2013). Al Jazeera. https:// www.aljazeera.com/features/2013/4/8/ bangladeshi-clerics-fight-atheistbloggers

Bhaumik, S. (2004). Ethnicity, ideology and religion: Separatist movements. In Satu P. Limaye, R.G. Wirsing and Mohan. M (Eds.), Religious radicalism and security in South Asia. Asia-Pacific Center for Security. https://apcss.org/ Publications/Edited\%20Volumes/ Religious Radicalism/ Pages from Religious Radicalismand Security in SouthAsiach10.pdf

Buehler, M. (2013). Subnational Islamization through secular parties: Comparing Shari'a politics in two Indonesian provinces. Comparative Politics, 46(1), 6382. https://www.jstor.org/stable/43664333 
Butler, D. (2015). Terrorism science: Five insights into jihad in Europe. Nature. https://www.nature.com/news/terrorismscience-5-insights-into-jihad-ineurope-1.18923

Butt, A. (2016). Street power: Friday prayers, Islamist protests, and Islamization in Pakistan. Politics and Religion, 9(1), 1-28. https://doi.org/10.1017/ S1755048316000031

Campos, N. \& Gassebner, M. (2009). International terrorism, political instability and the escalation effect. IZA Institute of Labor Economics. http://ftp.iza. org/dp4061.pdf

Castells, M. (2005). The network society: A cross-cultural perspective. Edward Elgar.

Combs, C. (2017). Terrorism in the twenty-first century (8th ed.). Routledge.

Dalacoura, K. (2006). Islamist terrorism and the Middle East democratic deficit: Political exclusion, repression and the causes of extremism. Democratization, 13(3), 508-525.

https://doi.org/10.1080/13510340600579516

Davies,L.(2009).Educating againstextremism: Towards a critical politicisation of youth people. International Review of Education. 55(2), 183-203.

https://doi.org/10.1007/s11159-008-9126-8

Davies, L. (2018). Review of educational initiatives in counter-extremism internationally: What works? The Segerstedt Institute Report. https://segerstedtinstitutet. gu.se/digitalAssets/1673/1673173_reviewof-educational-initiatives-180110.pdf

Dewan, A.H. (2013, May 6). Hefajat-e Islam's 13-point demand. The Daily Star. https:// www.thedailystar.net/news/hefajat-eislams-13-point-demand

Dhaka Metropolitan Police (DMP). (2018). Causes behind radicalization and a counter approach. Department of Criminology, University of Dhaka and DMP, Bangladesh Police.
Dunn, D. H. (2005). Bush, 11 September and the conflicting strategies of the 'war on terrorism'. Irish Studies in International Affairs, 16(11), 11-33. https://www.jstor. org/stable/i30001928

Ganguly, S. \& Riaz, A. (2016). Bangladesh's homegrown problem: Dhaka and the terrorist threat. Foreign Affairs. https:// www.foreignaffairs.com/articles/ bangladesh/2016-07-06/bangladeshshomegrown-problem

Ganguly. M. (2016). The Dhaka attacks were a product of Bangladesh's fractious politics. Human Rights Watch. https:// www.hrw.org/news/2016/07/11/dhakaattacks-were-product-bangladeshsfractious-politics

Geovasky, I. (2018). Terrorism from the perspective of identity politics. Center for Religious and Cross-Cultural Studies Graduate School, Universitas Gadjah Mada. https://crcs.ugm.ac.id/ perspective/12949/terrorism-from-theperspective-of-identity-politics.html

Griffiths, M. \& Hasan, M. (2015). Playing with fire: Islamism and politics in Bangladesh. Asian Journal of Political Science, 23(2), 226-241. https://doi.org/10.1080/0218537 7.2015.1040039

Hamid, A. F. A. (2001). Islamic resurgence: An overview of causal factors, a review of "Ummatic" linkages. IKIM Journal, 9(1), 15-47. https://www.academia. edu/549674/Islamic_Resurgence_An_ Overview_of_Causal_Factors_A_ Review_of_Ummatic_Linkages

Hasan, M. (2012). Geopolitics of political Islam in Bangladesh. Harvard Asia Quarterly, 14(1), 60-69. https://www. researchgate.net/publication/260833758_ Geopolitics_of_Political_Islam_in_ Bangladesh

Hassan, M., \& Nazneen, S. (2017). Violence and the breakdown of the political settlement: An uncertain future for Bangladesh? Conflict, Security $\mathcal{E}$ 
Development, 17(3), 205-223. https://doi. org/10.1080/14678802.2017. 1319695

Heathershaw, J. \& Montgomery, D. W. (2014). The myth of post-Soviet Muslim radicalization in the Central Asian Republics. Chatham House: The Royal Institute of International Affairs. https://www.caa-network.org/ wpcontent/ uploads/2015/04/20141111 PostSoviet Radicalization HeathershawMontgomery Final.pdf

Herbert, S. (2019). Conflict analysis of Bangladesh. K4D: Knowledge, evidence and learning for development. https:// reliefweb.int/sites/reliefweb.int/files/ resources/599_Bangladesh_Conflict_ Analysis.pdf

Huntington, S. P. (1996). The Clash of civilizations and the remaking of world order. Simon and Schuster.

Institute for Economics and Peace (IEP). (2016). Global terrorism index 2016. http:// eco nomicsandpeace.org/wp-content/ uploads/2016/11/ Global-TerrorismIndex-2016.2.pdf.

Islam M.R., Wahab H.A., Burmester C.F., Chowdhury S.R. (2019). Cultural globalization:Acriticalanalysisofidentity crises in the developing economies. In Faghih N. (ed.), Globalization and development. contributions to economics. Springer. https://doi.org/10.1007/978-3030-14370-1_16

Jabber, P. (2001). Impact of the war on terror on certain aspects of US policy in the Middle East. The National Intelligence Council. https://www.dni.gov/files/documents/ warterror_2001.pdf

Jackson, R. (2009) "The 9/11 attacks and the social construction of a national narrative," In Morgan, M. (Ed.), The impact of 9/11 on the media, arts, and entertainment: The day changed everything?. Palgrave Macmillan.

Jamil, U. (2014). Reading power: Muslims in the war on terror discourse. Islamophobia
Studies Journal, 2(2). https://doi. org/10.13169/islastudj.2.2.0029

Kabir, H. (2015). Beyond the Jamaat-e-Islami: The political rise of the Deobandis, the mystic leaders and Islamism in Bangladesh. In Mattson, I., NesbittLerking. P. \& Tahir, N. (Eds.), Religion and representation: Islam and democracy. Cambridge Scholars.

Lorch, J. (2020). Terrorism in Bangladesh: Understanding a complex phenomenon. Asian Survey: A Bimonthly Review of Contemporary Asian Affairs, 60(4). https:// doi.org/10.1525/as.2020.60.4.778

Mahmud, T. \&Shaon, A.I. (2018). Domilitants generally come from madrasa? Dhaka Tribune. https://www.dhakatribune.com/ opinion/special/2018/01/21/militantsgenerally-come-madrasas

Maizland, L. (2021). China's repression of Uyghurs in Xinjiang. Council on Foreign Relations. https://www.cfr. org/backgrounder/chinas-repressionuyghurs-xinjiang

Mitchell C., Stohl M., Carleton D. and Lopez G.A. (1986). 'State terrorism: Issues of concept and measurement'. In Stohl M. \& Lopez G.A. (Eds.), Government violence and repression: An agenda for research. Greenwood Press.

Bangladesh Enterprise Institute. (2011). Modernization of madrasa education in Bangladesh: A strategy paper. http://beibd.org/wp-content/uploads/2015/04/ Modernization-of-Madrassa-Educationin-Bangladesh-A-Strategy-Paper.pdf

Motafa, S. \& Doyle, N. J. (2019). Profiles of Islamic militants in Bangladesh, Perspectives on Terrorism, 13(5). https:// www.universiteitleiden.nl/binaries/ content/assets/customsites/perspectiveson-terrorism/2019/issue-5/8--mostofaand-doyle.pdf

Nelson, M.J. \&Oldmixon, S. (2018). Bangladesh on the brink: Mapping the evolving social geography of political violence. RESOLVE 
Network Report. https://resolvenet.org/ system/files/2018-10/RSVE_16-17BGD_ ResearchCompendium_FINAL.pdf

Njoku E.T. \& Akintayo J. (2018). 'Religious extremism'. In Leeming D. (Eds.), Encyclopedia of psychology and religion. Springer. https://doi.org/10.1007/978-3642-27771-9_200132-2

Porotsky, S. (2013). Pax Americana, the successful securitization of the triple threat of terrorism, 'outlaw' regimes, and weapons of mass destruction [Master's thesis, University of St. Andrews]. Academia. https://www.academia.edu/3482477/ Pax_Americana_The_Successful_ Securitization_of_the_Triple_Threat_ of_Terrorism_Outlaw_Regimes_and_ Weapons_of_Mass_Destruction

Putz, C. (2019, July 15). Which countries are for or against China's Xinjiang Policies? The Diplomat. https://thediplomat. com/2019/07/which-countries-are-for-oragainst-chinas-xinjiang-policies/

Raman, B. (2002). We will all become Taliban. Outlook. https://www.outlookindia. com/website/story/we-all-will-becometaliban/218257

Ramzy, A. \& Buckley, C. (2019). 'Absolutely no mercy': Leaked files expose how China organized mass detentions of Muslims. The New York Times. https://www. nytimes.com/interactive/2019/11/16/ world/asia/china-xinjiang-documents. html

Reed, A. (2016). Al Qaeda in the Indian Subcontinent: A new frontline in the global jihadist movement? Terrorism and Counter-Terrorism Studies, 8(1). https:// doi.org/10.19165/2016.2.02.

Riaz, A. (2016). Who are the Bangladeshi 'Islamist Militants'? Perspectives on Terrorism, 10(1). http://www. terrorismanalysts.com/pt/index.php/ pot/article/view/485/html

Riaz, Ali. (2014). A crisis of democracy in Bangladesh. Current History, 113(762),
150-156. https://doi.org/10.1525/ curh.2014.113.762.150.

Ross, H. (2003). Rethinking human vulnerability, security, and connection through relational theorizing. In Nelles, W.C. (Ed.). Comparative education, terrorism, and human security from critical pedagogy to peace building? Palgrave Macmillan.

Safi, M. (2017, May 26). Lady justice statue in Bangladesh is removed after Islamist objections. The Guardian. https:// www.theguardian.com/world/2017/ may/26/lady-justice-statue-bangladeshremoved-islamist-objections

Sageman, M. (2008). Leaderless jihad: Terror networks in the twenty-first century. University of Pennsylvania Press.

Said, E. (1998, January 2). Islam through Western eyes. The Nation. https://www. thenation.com/article/islam-throughwestern-eyes/

Said. E. (1981). Covering Islam: How the media and the experts determine how we see the rest of the world (Revised Edition). Vintage Books.

Shovon, F. (2020). Hefazat-e-Islam issues 24-hour ultimatum to shut down French embassy in Dhaka. Dhaka Tribune. https://www.dhakatribune.com/ bangladesh/2020/11/02/hefazat-e-islamprepares-for-march-towards-frenchembassy

Silber, M. D., \& Bhatt, A. (2007). Radicalization in the west: The homegrown threat. NYPD Intelligence Division.

Simpson,M.(2014). Terrorism and corruption. International Journal of Sociology. 44(2). 87-104. https://doi.org/10.2753/IJS00207659440204

Suleiman, M.N, \& Karim, M.A. (2015). Cycle of bad governance and corruption: The rise of Boko Haram in Nigeria. Sage Open, 5(1). https://doi. org/10.1177/2158244015576053 
Teitaulbam, J. F. (2017). Combatting prejudice: Understanding media prejudice toward Muslims and advocacy organizations' efforts to combat it [Master's thesis, Naval Postgraduate School, Monterey, California]. Naval Postgraduate School. https://calhoun.nps.edu/ handle/10945/56821

Uttom, S. \& Rozario, R. (2017). Dismay over the 'Islamization' of education in Bangladesh. LaCroix International. https://international.la-croix.com/ new s/education/dis m ay-overthe-islamization-of-education-inbangladesh/4609

Walter, E.V. (1969). Terror and resistance. Oxford University Press.
Whitlock, C. (2019). At war with the truth. Washington Post. https://www. washingtonpost.com/graphics/2019/ investigations/afghanistan-papers/ afghanistan-war-confidentialdocuments/

Wibisono, S., Louis, W. R. \& Jetten, J. (2019). A multidimensional analysis of religious extremism. Frontiers in Psychology, 10(1). https://doi.org/10.3389/fpsyg.2019.02560

Wright, J. (2019). State terrorism: Are academics deliberatelyignoringit? Journal of Global Faultlines, 6(2), 204-214. https:// doi.org/10.13169/jglobfaul.6.2.0204 